\title{
PRINCESA: THE TEXTUAL SPACE BETWEEN TRANSLATION AND DIVERGENCE
}

\author{
Laura Gandolfi \\ Princeton University \\ Translation from Spanish by \\ Matthew Tremé
}

This article examines Princesa, a testimonial text in which Fernanda Farias de Albuquerque, a Brazilian transvestite who emigrated to Italy in the early 1990s, narrates her life, from her childhood and adolescence in Brazil and through her trip to Europe. In the Roman prison of Rebibbia, Fernanda meets Maurizio Jannelli, a former member of the Italian Red Brigades sentenced to life for crimes related to the fighting of the seventies, and Giovanni Tamponi, a Sardinian shepherd imprisoned for various armed robberies. Fernanda, Maurizio and Giovanni will give life to this peculiar and hybrid text, Princesa, considered one of the first examples of the so called "Italian literature of migration".

Keywords: Fernanda Farias de Albuquerque, literature of migration, testimonial narrative, translation, Red Brigades, sertão.

Sensibili alle foglie (Sensitive to leaves), as can be read on the Italian cooperative/publisher's webpage, "is another way of looking. Above all, it is another way of doing social research and of giving that research back to society at large. With texts that grant the right to speak to women and men who, in some way, had lost it or had had it taken away."1 Founded in 1990 by Renato Curcio, Nicola Valentino and Stefano Petrelli, all ex-militants of the Italian Red Brigades

\footnotetext{
${ }^{1}$ The translation into English is mine (www.sensibiliallefoglie.it).
} 


\section{Laura Gandolfi}

who were serving out their sentences in the Roman prison of Rebibbia, the cooperative was proposed from its inception as a cultural and editorial alternative that sought to create a space in which "muted voices" could be recovered and expressed, and to narrate experiences that were at the margins of the narratable. Together with social research texts that explore prisons or mental institutions and other works dedicated to inquiry into the so-called "Lead years" in Italy, Sensibili alle foglie played and continues to play a fundamentally important role in the publishing sphere in regards to the diffusion of texts that belong to what Italian critic Armando Gnisci denominated "Italian literature of migration."

In this sense, we could affirm that the cooperative took up and tried to flesh out the statement made by Joseph Brodsky in a lecture given in 1987, in which the Russian-American poet stated in reference to the phenomenon of migration, that "whatever the proper name for this phenomenon is, whatever the motives, origins, and destinations of these people are, whatever their impact on the societies which they abandon and to which they come, one thing is absolutely clear: they make it very difficult to talk with a straight face about the plight of the writer in exile. Yet talk we must" (23). What we are dealing with, then, is an emergency closely linked to what literature is, or should be, that is to say, "the greatest [...] teacher of human subtlety," as Brodsky himself affirmed (23). Thanks to Sensibili alle foglie, the voices of many "migrant writers" managed to find a space in which to narrate the experiences of lives lived at the margins, the stories of geographic and identitarian displacements, and the divergences and failed encounters with new cultures and social realities. ${ }^{2}$ One of these early voices belonged to

\footnotetext{
${ }^{2}$ Let us recall, to mention only a few examples: Lontano da Baghdad (Far from Baghdad), written by Laitef Thea, an Iraqi who emigrated to Italy in the early 90's, and which relates the experience of the war in Iraq and the author's first contact with Europe; La tana della iena (The Hyena's Den) by Palestinian author Hassan Itab, which tells about the author's participation in armed resistance in the Middle East and the time he spent in Italian jails; Romane KRLE. Voci zingare (Romane KRLE, Gypsy
} 
Fernanda Farias de Albuquerque, a Brazilian transvestite who emigrated to Italy in the early 1990s and was later imprisoned in Rebibbia for attempted homicide. In Princesa, published in Italy in 1994 and then in Brazil in the following year, ${ }^{3}$ Fernanda narrates her life, from her early childhood and adolescence in Alagoa Grande and then through the trip to Europe that eventually led to her imprisonment in Italy and the writing of her story.

Recognized as one of the first examples of the relatively recent Italian narrative of migration, Princesa is a text that questions and problematizes the very notion of identity, not only in relation to this migratory phenomenon and its spatial displacement, but also in relation to the implicit (and perhaps necessary) questioning of the dichotomic structure that defines the masculine and feminine genders. Furthermore, the fact that the text has been and continues to be considered as belonging to contemporary Italian literature (regardless of the fact that Fernanda de Albuquerque is by nationality Brazilian, and a large part of the text indeed deals with her life in Brazil, not Italy) necessarily generates a series of questions pertaining to national literary frameworks and the boundaries that in this case define Brazilian literature, on the one hand, and Italian, on the other. The purpose of this brief essay, then, is to offer a reflection on a text about which little has been written to date. ${ }^{4}$ Initially we will consider Princesa in the context of Italian literature of migration, in order to later acknowledge it as a concrete example of the possibility of a "third space" of geography, of gender and of narrative;

Voices), a collection of autobiographical testimonies, short stories, poems and plays by Romanian émigrés, published in 1992.

3 A Princesa: depoimento de um travesti a um líder das Brigadas Vermelhas. Rio de Janeiro: Nova Fronteira, 1995.

${ }^{4}$ Although various texts on the literature of migration in Italy mention Princesa (see Graziella Parati and Armando Gnisci, for example), a study dedicated wholly to its analysis, both in Italy as well as in Brazil, is lacking.

${ }^{5}$ Here I am referring to the concept of "third space" elaborated by Homi Bhaba in "DissemiNation: Time, Narrative and the Margins of the Modern Nation," and also the notion of "third term" developed by Marjorie Garber in Vested Interests: Cross Dressing \& Cultural Anxiety. 


\section{Laura Gandolfi}

that is, as a place of encounters, both successful and failed, between Brazil and Italy, between feminine and masculine, and between testimony, autobiography and novel. The central questions around which this analysis will revolve include: In what way does Fernanda de Albuquerque's text dialogue with the narrative corpus of the so-called literature of migration? To what degree should Princesa be recognized as Italian literature and not Brazilian literature written in Italian? What should we make of the linguistic peculiarities that mark the text? And, finally, what type of discourses can a text that indirectly problematizes the very concepts of literary genre and authorship generate?

In one of the first studies that sought to research Italian literature of migration, Armando Gnisci considered those texts published in the early nineties as "books [that] make us see Italy and Italians against the grain, according to the famous expression by Walter Benjamin, [texts that] reveal, above all, the superfluous and fastidious condition of the immigrant to the north" (La letteratura 36$).{ }^{6}$ In other words, the texts to which Gnisci refers problematize a social reality that is specifically Italian, and which was undergoing a period of transition with regard to the migratory phenomenon. ${ }^{7}$ These first examples of literature of migration share, on the one hand, a testimonial and/or autobiographical character and, on the other, a more or less binding collaboration between the migrant writer -"the wretched of migration" (Gnisci, La letteratura 36)- and a second person, a coauthor who collaborates in the final version of the text in Italian. That is to say, this phenomenon deals with narratives in which the theme of migration predominates; these are texts that are delimited, to a certain degree, by the narration of a social reality that in those years was intensifying in Italy.

Princesa could be considered as an example of testimonial narrative, which is to say, in the words of John Beverley,

\footnotetext{
${ }^{6}$ All translations to English of Gnisci's texts are my own.

${ }^{7}$ As Gnisci has pointed out, it was in the 1970s that the Italian migratory paradigm transformed definitively, changing from what had always been a country of émigrés into one of immigrants ("Perdurabile" 131).
} 
that it deals with a "novel or novella-length narrative [...], told in the first person by a narrator who is also the real protagonist or witness of the events he or she recounts, and whose unit of narration is usually a 'life' or a significant life experience" (Testimonio 30). Likewise, the text is born through a collaboration between the author and coauthor and the writing has been made possible through the presence of a "mediating subject" that facilitates the redaction of the text and/or its subsequent diffusion. It is in this regard that Princesa conforms to the constitutive characteristics that frame this first phase of Italian narrative of migration (see Sinopoli). The text is thus classified by genre according to two different traditions of testimonial narrative -the Italian and the Latin American- that are born of and respond to very different and highly specific socio-historic situations. While in the case of Italy the so-called "testimonianza" necessarily implies a link to World War II and, particularly, the drama of the Holocaust, ${ }^{8}$ in the case of Latin America, we are dealing with a genre that simultaneously dates back to the hemisphere's colonial past, during which time the act of writing (diaries, letters and relations) required a legitimated eyewitness in order to relate history, and also the national liberation movements of the sixties. ${ }^{9}$

Nevertheless, the peculiarities and narrative-constitutive dynamics that shape Fernanda's text undoubtedly distinguish it from the corpus of works that up to that time had been published in the field of Italian literature of migration. The process of writing in Princesa, in particular, arises from the collaboration, or the co-presence if you will, of three different voices: Fernanda, Maurizio Jannelli and Giovanni Tamponi. Here, the traditional binomial of informant/ subaltern/ witness versus mediator/ transcriber/ translator, which is a constant fixture of the testimonial genre, is altered by the presence of a third subject that does not fit these other two categories and yet, actively participates in the creation

\footnotetext{
${ }^{8}$ See, for example, Primo Levi, Liana Millu or Giuliana Tedeschi.

9 On testimony in Latin America, see, among others, John Beverley's Testimonio: On the Politics of Truth and George Yúdice's "Testimonio and Postmodernism."
} 


\section{Laura Gandolfi}

of the text. Giovanni, a Sardinian shepherd sentenced to life in prison for various armed robberies, becomes the only direct interlocutor for Fernanda's oral narrations, and represents this "third presence."

In the "brief notes of context" that act as the introduction to the text, Maurizio Jannelli, an ex-brigade member also sentenced to life in prison for crimes related to the armed fighting of the seventies, writes that "a profound crisis brought Fernanda to the threshold of the irreparable," that "Giovanni, who in his turn had written autobiographical short stories about his experience as a shepherd, recommended the medicine she needed: write in order to stay together, to resist the devastating action of reclusion, to not forget having been born free" (7). The Sardinian shepherd, therefore, positions himself in the space of a hybrid "other", one that is contemporarily internal and external to the process of writing. Giovanni's participation was internal to the act of writing in that the origin of Princesa, or what we should really call its initial outlines, are nothing short of the oral tales of Fernanda, which would not have been possible without the interlocution of the shepherd. His participation was also external in that it was thanks to him that Fernanda's notebooks were able to cross the physical boundaries of the prison that separated transsexuals from the political prisoners. In other words, Giovanni was the "material" (and/or corporeal) mediator that facilitated the transfer of Fernanda's testimony from her cell to Jannelli's. This triple structure, then, subsequently problematizes the question of authorial discourse. We are no longer in the presence of the dichotomic model in which one "weak" voice and another "strong" one diverge in the textual space. ${ }^{11}$ What we are dealing with here, rather, is a drastic

\footnotetext{
${ }^{10}$ All translations from Princesa are my own.

${ }^{11}$ Our intention here is not to claim that the informer/mediator relationship necessarily implies a dynamic in which a negative term confronts a positive one, a matter about which much has already been written. John Beverley, for example, affirmed in 1991 that "the possibilities for distortion and/or cooptation in such a situation, [the mediated narrative], are many $[\ldots]$. But one of the things that can be said in its favor is that it can serve as both an allegorical figure for, and a concrete means of, the
} 
but involuntarily subversive genesis, as Jannelli himself underscores:

\begin{abstract}
our thoughts, discussions, our days, abruptly deviated toward unexplored territories. Fernanda introduced us to an unknown world, that of transsexuals. Her writing produced another writing, my own. Slowly, each one directed to the others, we opened a space for encounters, reciprocal knowledge, and infinite other games stolen from the watch of the guards. Like three tightrope walkers we followed each other, unsure, along the thread of a spiral epistle that took us beyond the walls, beyond the jail. That's how Princesa was born. From an irregular encounter, from three stories, three people who landed in jail following different routes: mine was through armed resistance in the Red Brigades, Fernanda's was transsexual prostitution, Giovanni's was pastoral life and armed robbery. (78 , emphasis mine)
\end{abstract}

The narration of Fernanda's life, in this sense, is an integral part of a much more complex process of writing, into which the silent and apparently absent experiences of Jannelli and Tamponi are interwoven. With this we do not mean to say that the text does not present a dynamic of transcription, translation and mediation - Jannelli has effectively transcribed, translated and mediated Fernanda's original version. However, this practice of writing, far from being limiting, becomes a space of convergence in which each voice and each alterity are mutually recovered, and where "neither of the participants has to cancel its identity as such" (Beverley, "Through All" 4). The text, in this regard, would be transformed, using Beverley's words, into a "discursive space where the possibilities of such an alliance can be negotiated on both sides without too much angst about otherness or "othering"" ("Through All" 4). It is through the act of narrating, and the subsequent transcription of the story, that Fernanda appears to constitute herself/become constituted as a subject of enunciation. This process of testimonial narration complicates and, to a certain degree, redefines the dynamics that guide the very notion of

union of a radicalized (Marxist) intelligentsia with the subaltern" (“Through All” 4). 


\section{Laura Gandolfi}

subjectivity. As Giorgio Agamben affirmed in his reflections on testimony and the Shoah, the act of speaking, of testifying, inevitably implies a process of de-subjectification in which the "I" of the enunciation never totally coincides with the speaking subject. Testimony, in this sense, would be defined through the aporia of the "de-subjectification of each subjectification", with testimony itself being "a potentiality that becomes actual through an impotentiality of speech; [...] an impossibility that gives itself existence through a possibility of speaking" (146).

The idea of Princesa as a generator of a "third space" also takes cues from the linguistic discourse at work in its construction. Fernanda wrote her notebooks in a sort of hybrid language, a convergence of her native Portuguese, the Sardinian dialect that she picked up through her conversations with Giovanni, and Italian, which is the language of the text's final published version. ${ }^{12}$ Jannelli notes:

In order to communicate with Fernanda, I participated and contributed in the making of a 'new language.' In the variation, both written and oral, that resulted from the chemistry of our mother tongues. Portuguese, Italian, and Sardinian. With regards to the latter, in the original writings of Fernanda, there are delicious marks that trace back to her teacher. Created only for us, the original writing has been successively manipulated so as to be accessible to a wider audience. (9-10)

The linguistic pastiche that shapes the original writings, then, undergoes a process of rewriting and manipulation that transforms the text into a more homogeneous and intelligible (that is to say, sellable) "product." No matter how visible this practice of linguistic manipulation may be in the final draft created by Jannelli, it is important to also consider the process of translation carried out by Fernanda herself during the writing of the first version of Princesa. Her decision to write in Italian implies a double dynamic at work: on the one hand, a progressive distancing from her native language and,

12 The original version has never been published in its entirety. The magazine "Caffè" published some fragments in 1994. 


\section{Princesa}

on the other, the process of appropriation of the new language. This practice of translation highlights a more concrete cultural displacement, a movement through which Fernanda distances herself from the Brazilian literary tradition in order to enter into a purely Italian context. As Graziella Parati has affirmed in Migration Italy: The Art of Talking Back in a Destination, we are dealing here with an appropriation that is really a negotiation between the linguistic difference of the migrant writer, standard Italian, and the dialectical variations of the "new language" (55). ${ }^{13}$ This structure characterized by the co-participation of three elements, in the case of Princesa, is even more determining, precisely thanks to the relationship between Fernanda and Giovanni. For Parati, the use of Italian should be considered a practice of separation not just from the other language, but also from the native cultural context and, in a parallel way, as a vehicle to foment a dialogue between the different narratives and migratory experiences in the country (59-60). In the case of Princesa, then, we could speak of a practice of "self-translation" more than of translation per se; insofar as she is Brazilian, Fernanda translates herself, in an act that is not limited just to concrete linguistic translation, but also to the wider etymologic meaning of the Latin traducere, meaning "to lead someone from one place to another" (Pianigiani 1451) and "to explain, interpret" (Pianigiani 1451). ${ }^{14}$ In other words, Fernanda translates herself by explaining and interpreting herself through an act of linguistic, spatial, and identitarian appropriation that inevitably recalls her migratory experience; Fernanda leads herself to Italy as she separates herself from Brazil. She

\footnotetext{
${ }^{13}$ On this subject, Parati reflects on the peculiarity of the Italian language, which was imposed as the national language following the political unification of the peninsula. This imposition could only be detrimental to what are now commonly called "dialects". This dynamic, Parati claims, creates conditions under which the native speaker of Italian cannot completely appropriate the language: "this infiltration of dialectal variants within the language reveals that a native speaker of Italian 'owns' the language and is, at the same time, a stranger to it. Consequently, the national language, and the native speaker cannot really own it" (55).

${ }^{14}$ The translation to English is mine.
} 


\title{
Laura Gandolfi
}

creates an "other" space or, taking up Homi Bhaba again, an "in-between space [...] [that] provide[s] the terrain for elaborating strategies of selfhood - singular or communal that initiate[s] new signs of identity, and innovative sites of collaboration, and contestation, in the act of defining the idea of society itself" (The Location 2). This is a space that simultaneously is and is not Brazil, is and is not Italy, is and is not prison, is and is not Fernanda, just as it is also, or neither, Giovanni and Maurizio.

These suppositions allow us to consider Princesa as a text that par excellence defines itself by the dynamics that are intrinsic to the very act of translation, understood here as the multiple displacements that we have described. It is a dislocation (or, better still, a re-location) that foregrounds the trip that brought her from Brazil to Spain and, finally, Italy. However, these geographic displacements (translations) are not limited solely to this trajectory, but rather, they represent a constant throughout her childhood and adolescence, to wit, the practice of flight that, in this instance, better defines the link between spatial context and subject (as the construction of an identity and/or alterity). In one of the first pages of her text, Fernanda writes:

\begin{abstract}
Cattle and farming lay out a flat land to the north of the Farias house. But the south unexpectedly changes into a lush green with birds and hunters. A break of dense shadows, an old cut of gnawed jungle. Flattened. Many hours of travel before the desolation of the caatinga -the delay of many devils, bandits and saints- burns everything into the persistence of the desert. A crumbled land, steps that sink, stains of thorns and aridity. Quickly, in the East, toward Remigio, three highways with six lanes head for Campina Grande, João Pessoa and Picuí. (16)
\end{abstract}

Fernanda was born and spent the first years of her life here, in this family space from which she would always try to flee, but to which she would also desire to return. She describes a harsh, inhospitable place so extreme that it would only allow holiness or condemnation. What she describes is the sertão, that great geographic topos of Brazilian literature in which the characters of Euclides da Cunha, Graciliano Ramos, João Guimarães Rosa or José Lins do Rego 
materialize (or dissolve), and which also became a leitmotif in cinema and music. ${ }^{15}$ The context of the sertão brings us back to an unresolved tension between civilization and barbarism, the human and the inhuman, sanity and madness; it is the space par excellence of transcendence, magic and boundaries, but also of human potential. Fernanda's sertão would appear to approach the alienating space of Morte $e$ vida severina. That is to say, it is a sertão that is no longer "the World" or, better still, is "the World" that must be escaped in order to seek out other worlds. "One possibility," Fernanda writes, "is flight. The other, suicide" (35). And thus begins her infinite journey, which from Alagoa Grande will carry her to Campina Grande, João Pessoa, Recife, Natal, Salvador, Rio and, finally, São Paulo, before flying to Europe. Fernanda's travels, as she characterizes them, were no less than a series of spatial displacements whose constants were necessity, emergency or flight: "I didn't depart in order to arrive, I fled and that's it" (38); "To Natal! [...] three hundred kilometers, a flight of five hours" (45); and also "on the bus to Salvador I was gaining distance to the south of Sítio. A thousand kilometers were not enough. I looked back and I fled. Once again. I couldn't see anything ahead, I didn't know what was ahead. Only God knows what's ahead" (52).

Likewise, Fernanda's geographic movements are heightened in urban spaces, where the dynamism and almost delirious street rhythms of the city stand in stark relief to the sertão's imposing immobility. In Brazil, and then Spain and Italy, her contact with the urban context seems to implicate, to borrow the expression from Michel de Certeau, "a process of appropriation of the topographical system" through which the act of walking becomes the true "space of enunciation" (97-98). Fernanda notes:

I walk through bottlenecks and openings, along dark walls and silent and unknown palaces. I glide, imitating in the steps of a

See, for example, Walnice Nogueira Galvão's "Metamorfoses do sertão" for an analysis of the transformations, or "resemantizations", of the sertão in Brazilian cinema. 


\section{Laura Gandolfi}

man, through nocturnal gazes, alert eyes that stop my heart and breath. [...] The unknown city ferments an anxiety that becomes chaos inside of me, it is the whole world that threatens me, that escapes my control. I am alone. (37)

On another occasion, she writes about Recife, "I know the city, I walk it at night. It is dark, and yet I see lines and confines that cannot be passed. I skirt the dangerous territories and then move away from them. I discover routes and hiding places. I know where to walk" (40). These "pedestrian travels," which appear systematically in Fernanda's recollections, can be viewed as attempts to appropriate space. That is, they are acts through which an identitarian alterity is constantly reiterated, reminding us of de Certeau's claim that "to walk is to lack a place. It is the indefinite process of being absent and in search of a proper" (103). Fernanda's wanderings are along a path that is not just spatial; her search is for a place that could oppose this "world that harbored no fantasies about inventing her, only despising her" (Albuquerque and Jannelli 38).

To that end, flight from the sertão was necessary because there, for everyone, Fernanda was just a "manandwoman," a veadinho, a hybrid being whose otherness her family could not accept. ${ }^{16}$ After having left Recife for Natal, Fernanda writes in a letter to her mother Cícera: "I left because I am not a man. I don't like women; I was born to love men. You refuse to understand. [...] Everyone in Remigio looks down on me. I didn't have the courage to declare myself in front of you. I will return when my shame is gone" (51). And this is how, through a progressive and constant movement away from her homeland, and likewise in the brief spatial wanderings through urban settings, Fernando slowly becomes Fernanda:

Light pupils, flowers in the windows: here are her eyes. A stage.

Fernanda, my new freedom, like a first time actress takes the

\footnotetext{
16 It would be interesting to reflect on the theme of androgyny or hermaphrodism related to the primordial and mythic space of chaos. See, among others, L'hermaphrodite by Michel Serres and Androgino, il mito, l'arte, la merce by Cecilia Gatto Trocchi.
} 


\section{Princesa}

stage. [...] I am there, excised, harmless, while Fernanda sparks and tells her own story, a whore and student. I look at her, at myself. Backed into the corner of the seat, I travel through the city at night. [...] Fernando, I am a spectator of myself. Fernanda, unexpected and free, surprises me. [...] She inhabits my body and swallows my tail, the snake. Here I am, manandwoman, with a José-with-me and the desire that satiates us as we travel down an unknown boulevard that separates from the city. Now I know, one blow will be enough to knock down the house of cards. (36)

This name change, which is only made possible upon leaving the sertão, acknowledges the need to translate a gender that subverts the dichotomic structure of man/woman. ${ }^{17}$ Fernando/a's transformation, in particular, is shaped through a performative dynamic -a process of excision of the self, we could say- in which the fragmentation of sexual identity seems to imply a positive crisis. In this regard Fernanda accepts her condition of "manandwoman," seen through the affirmation of her alterity -"here I am." The body here becomes the text on which an "other" sexuality is inscribed and is the space where an unavoidably performative identity materializes. ${ }^{18}$ The earliest childhood fantasies of Fernanda -"two halves of coconut were my first breasts. [...] My fantasy, a round belly and a little girl's slit" (16)- are later realized with body writing whose ink is a mixture of hormones and silicon through which "Fernando is slowly consumed. His penis shrinks, his testicles withdraw. His hair thins out, his sides

17 "One of the most important aspects of cross-dressing," affirms Marjorie Garber, "is the way in which it offers a challenge to easy notions of binarity, putting into question the categories of 'female' and 'male,' whether they are considered essential or constructed, biological or cultural" (10).

${ }^{18}$ According to Judith Butler, "acts, gestures, and desire produce the effect of an internal core or substance, but produce this on the surface of the body, through the play of signifying absences that suggest, but never reveal, the organizing principle of identity as a cause. Such acts, gestures, enactments, generally construed, are performative in the sense that the essence or identity that they otherwise purport to express are fabrications manufactured and sustained through corporeal signs and other discursive means" (185). 


\section{Laura Gandolfi}

widen," as simultaneously, "Fernanda grows. Piece by piece, gesture by gesture, I go down to earth from heaven, a devil a mirror. My trip" (57).

Transvestism, first, and then body modification, later, highlight the urgency of the search for a "third space" or a "third term" (Garber 11). As Marjorie Garber has affirmed, "the third is a mode of articulation, a way of describing a space of possibility. Three puts in question the idea of one: of identity, self-sufficiency, self-knowledge" (11). A unity, in other words, that Fernanda tried to construct by translating the untranslatable, by building a copy -of Sônia Braga (41) or of Roberta Close (Albuquerque and Jannelli 57)- that can exist only through a dynamic of perennial displacement. A unity, in short, that she could find neither in Brazil where she walked the streets selling her body, nor in Italy where in a world of prostitution and drugs Fernanda "had no future and just stumbled around in the darkness" (Albuquerque and Jannelli 101).

And so, it is precisely in this sense that Princesa can be seen as a paradigmatic example of a geographic, gendered and narrative "interstitial space" (Bhaba, "DissemiNation" 312) in which Fernanda (together with Maurizio and Giovanni) constructs and reconstructs herself continuously. As Sergia Adamo has affirmed, the collaboration/translation that lies at the heart of Princesa, and many other works of the literature of migration, inevitably invoke a dynamic in which "the subject [...] always depends on translation" (200). ${ }^{19}$ However, it is possible "to reconsider the conceptual metaphor of translation, not to sanction, but to cast into doubt," highlighting "the potential for change, for reaction and action that can arise" (205). In the case of Princesa, the metaphor of translation is crucial not only in terms of linguistic transference, but also for the creation of a narrative governed by the multi-pronged ability of translation to transfer languages, experiences, subjects, and spaces. Furthermore, it works with a life story that, like "all life stories, [does not] have an author" (Cavarero 58). It is in this

${ }^{19}$ The translations to English are my own. 
"third space" where, however momentarily, the boundaries between Brazil and Italy, between masculine and feminine, between the cellblocks of the political prisoners and the transsexuals, seem to be erased - or in some cases actually are erased. These boundaries, in spite of being propped up by political dynamics of power and violence, can nevertheless generate alternative, positive possibilities, when questioned or problematized by something or someone.

\section{Works Cited:}

Adamo, Sergia. "La traduzione come metafora concettuale." Culture planetarie. Roma: Meltemi, 2007. 193-211.

Agamben, Giorgio. Remnants of Auschwitz: The Witness and the Archive. Trans. Daniel Heller-Roazen. New York: Zone Books, 1999.

Albuquerque, Fernanda Farias de, Maurizio Jannelli. Princesa. Roma: Sensibili alle foglie, 1994.

Beverley, John. “'Through All Things Modern': Second Thoughts on Testimonio. Boundary 2.18 (1991): 1-21.

---. Testimonio: On the Politics of Truth. Minneapolis: University of Minnesota Press, 2004.

Bhabha, Homi. "DissemiNation: Time, Narrative and the Margins of the Modern Nation." Nation and Narration. London: Routledge, 1990. 291-322.

---. The Location of Culture. London: Routledge, 1994.

Brodsky, Joseph. "The Condition We Call Exile, or Acorns Aweigh." On Grief and Reason. New York: FSG, 1995. 22-34.

Butler, Judith. Gender Trouble: Feminism and the Subversion of Identity. London: Routledge, 2006.

Cavarero, Adriana. Tu che mi guardi, tu che mi racconti: filosofia della narrazione. Milano: Feltrinelli, 1997.

Certeau, Michel de. The Practice of Everyday Life. Trans. Steven Rendall. Berkeley: University of California Press, 1984. 
Galvão, Walnice Nogueira. "Metamorfoses do sertão." Estudos Avançados. 18.52 (2004): 375-394.

Garber, Marjorie B. Vested Interests: Cross Dressing \& Cultural Anxiety. London: Routledge, 1992.

Gatto Trocchi, Cecilia, ed. Androgino, il mito, l'arte, la merce. Perugia: Margiacchi-Galeno, 1997.

Gnisci, Armando. La letteratura italiana della migrazione. Roma: Lilith, 1998.

---. "Perdurabile migranza." Creolizzare l'Europa: letteratura e migrazione. Roma: Meltemi, 2003. 131-170.

Parati, Graziella. Migration Italy: The Art of Talking Back in a Destination Culture. Toronto: University of Toronto Press, 2005.

Pianigiani, Ottorino. Vocabolario etimologico della lingua italiana. Roma/Milano: Abrighi, Segati e C., 1907.

Serres, Michel. L'hermaphrodite: Sarrasine sculpteur. Paris: Flammarion, 1987.

Sinopoli, Franca. "Poetiche della migrazione nella letteratura italiana contemporanea: il discorso autobiografico." Studi e testi italiani 7 (2002): 189-206.

Yúdice, George. "Testimonio and Postmodernism." Latin American Perspectives 18.3 (1991): 15-31. 